\title{
COMUNICARE ȘI COMUNIUNE. BISERICA ŞI LIMBAJUL EI ÎN SOCIETATE Editorial
}

Dumitru A. VANCA ${ }^{1}$

Prezentul volum strânge laolaltă o parte dintre comunicările studenților doctoranzi prezentate în cadrul Școlii Internaționale de Vară a Doctoranzilor Teologi (cunoscută sub abrevierea SIVDT 2019). Eveniment ajuns la a VII-a ediție, întrunirea științifică anuală, organizată de Școala Doctorală de Teologie Ortodoxă din Universitatea „1 Decembrie 1918”, este deja una dintre manifestările științifice cunoscute și așteptate de către tinerii studenți doctoranzi din întreaga țară. Sub patronajul Facultății de Teologie Ortodoxă din Alba Iulia, cu sprijinul logistic al Universității „1 Decembrie 1918” și cel financiar al Consiliului Județean Alba, SIVDT 2019 a primit binecuvântarea Înaltpreasfinţitului Părinte Irineu, Arhiepiscopul Alba Iuliei. Nu putem să nu ne exprimăm recunoștința noastră față de obștea Mănăstirii „Sfântul Mare Mucenic Dimitrie" din Sighișoara, în special părintelui stareț, care ne-a pus la dispoziție spațiile de întruniri, trapeza mânăstirii și o parte din spațiile de cazare pentru cei aproape 100 participanți.

Manifestarea a început, cum este firesc, prin săvârșirea Sfintei Liturghii, urmată de un Te-Deum în biserica mânăstirii. În sesiunea de deschidere au fost transmise mesajul și binecuvântarea Înaltpreasfinţitului Părinte Arhiepiscop Irineu, prin Pr. Oliviu BOTOI, Consilier cultural al Eparhiei Alba Iuliei, și au adresat cuvinte de salut decanul Facultății de Teologie Ortodoxă și Directorul IOSUD-UAB, și un cuvânt duhovnicesc părintele Ghelasie ȚEPEȘ, starețul Mânăstirii Sfântului Dimitrie.

Având ca temă generală Comunicare şi comuniune. Biserica şi limbajul ei în societate, întâlnirea a fost propusă tinerilor cercetători ca o

${ }^{1}$ Preot, profesor, directorul Școlii Doctorale de Teologie din cadrul Universității „1 Decembrie 1918” din Alba Iulia. 
platformă de dezbateri, dialog și polemică științifică a doctoranzilor din țară şi din străinătate, din domeniul studiilor teologice. Întrucât experiența anilor trecuți ne-a făcut să înțelegem că o unică temă este mult prea restrictivă, mai ales pentru cei care nu au cercetări precise pe tema sugerată de Sfântul Sinod al Bisericii Ortodoxe Române - Anul omagial al satului românesc (al preoților, învățătorilor și primarilor gospodari) și Anul comemorativ al Patriarhilor Nicodim Munteanu și Iustin Moisescu și al traducătorilor de cărți bisericești în Patriarhia Română, organizatorii au permis participanților și prezentarea unor comunicări axate pe propriile cercetări. Din acest motiv, în paginile acestui număr (primul dintr-o serie de trei volume găzduite de revista Altarul Reîntregirii), cititorii pot găsi și alte teme, nu doar cele care au ca obiect al cercetării satul românesc ori traducătorii de cărți bisericești.

Gândită nu doar ca o reuniune științifică, ci și ca un eveniment didactic pentru instruirea și antrenarea cercetătorilor din domeniul teologie în activităţi utile în munca de cercetare, întâlnirea de la Sighișoara din 7-9 iulie 2029, a organizat șapte importante workshop-uri destinate unor aspecte tehnice și complementare activitătii de cercetare-publicare și douăsprezece comunicări științifice ale cadrelor didactice, pe teme încadrate în propriile culoare de cercetare. La Sighișoara au fost prezenți aproape 70 de doctoranzi din toate școlile doctorale de teologie din România $^{2}$. Cercetările prezentate în cele patru paneluri au fost în multe situații foarte diverse, acoperind subiecte istorice, biblice, de bioetică și morală, misiologie, liturgică, muzică și drept canonic... practic, toate marile teme de cercetare au fost prezente la SIVDT 2019.

Procesul de selecție, revizie, corectare și adaptare a textelor la normele de publicare ale revistei Altarul Reîntregirii a presupus un efort considerabil, pentru care trebuie să mulțumesc în special domnului drd. Alexandru AGIGNOAEI, de la Universitatea „1 Decembrie 1918", care a fost implicat nu numai în logistica și

${ }^{2} \mathrm{O}$ listă completă a comunicărilor prezentate se poate consulta în editorialul extins şi publicat în Revista Altarul Reîntregirii, Nr.1/2019, p. 7-12. 
organizarea evenimentului, dar și cel care a asigurat legătura permanentă cu participanții. Mulțumiri se cuvin și domnilor doctoranzi Marius CĂLDĂRARU (Universitatea din București) și Luminița IVANOVICI (Universitatea „Babeș-Bolyai) pentru contribuția în aducerea tuturor materialelor la forma finală. 